\title{
High Exposure to Toxoplasma gondii and Neospora Spp. in Donkeys in Israel: Serological Survey and Case Reports
}

\author{
Sharon Tirosh-Levy ${ }^{1,2}{ }^{(D)}$, Amir Steinman ${ }^{1}{ }^{(\mathbb{D}}$, Avital Minderigiu ${ }^{1}$, Ori Arieli ${ }^{1}$, Igor Savitski ${ }^{2}$, \\ Ludmila Fleiderovitz ${ }^{2}$, Nir Edery ${ }^{3}$, Gili Schvartz ${ }^{1,4}\left(\mathbb{D}\right.$ and Monica Leszkowicz Mazuz ${ }^{2, *}$ \\ 1 Koret School of Veterinary Medicine, The Robert H. Smith Faculty of Agriculture, Food and Environment, \\ The Hebrew University of Jerusalem, Rehovot 7610001, Israel; sharontirosh@gmail.com (S.T.-L.); \\ amirst@savion.huji.ac.il (A.S.); avitalmind@gmail.com (A.M.); oriarieli6@gmail.com (O.A.); \\ giliun@gmail.com (G.S.) \\ 2 Division of Parasitology, Kimron Veterinary Institute, Bet Dagan 50250, Israel; igors@moag.gov.il (I.S.); \\ ludaf@moag.gov.il (L.F.) \\ 3 Division of Pathology, Kimron Veterinary Institute, Bet Dagan 50250, Israel; nire@moag.gov.il \\ 4 Division of Virology, Kimron Veterinary Institute, Bet Dagan 50250, Israel \\ * Correspondence: monical@moag.gov.il; Tel.: +972-3-968-1690
}

Received: 16 September 2020; Accepted: 14 October 2020; Published: 19 October 2020

Simple Summary: Toxoplasma gondii and Neospora spp. are major pathogenic parasites of animals worldwide, with the first also affecting humans. These parasites have two-host life cycles, with the cat and the dog being the definitive hosts of T. gondii and N. caninum, respectively. Both parasites can infect various animal species, as intermediate hosts, in which they form tissue cysts and may cause abortions and neurological disease. Both parasites have been reported in wild and domestic animals in Israel. This study aimed to evaluate the serologic exposure of donkeys to these parasites. A total of 98 donkeys were examined. Half of them $(n=49)$ were from animal shelters in Israel, and the rest $(n=49)$ were working donkeys from the Palestinian Authority. Anti-T. gondii antibodies and anti-Neospora spp. antibodies were found in $94 \%$ and in $70 \%$ of the donkeys, respectively. In addition, two cases of donkeys presenting $N$. caninum tissue cysts, which were detected during post-mortem examination, were described. This is the first report of the exposure of donkeys to Toxoplasma gondii and Neospora spp. in the area. The exposure of donkeys to both parasites was considerably higher than the exposure of other species in the area and may be the result of poor husbandry conditions and higher exposure to infection. These results indicate that donkeys may have an important role in the maintenance and transmission of these parasites.

Abstract: Toxoplasma gondii and Neospora spp. are closely related cyst-forming coccidian parasites, which infect various animal species and have considerable zoonotic and economic implications, respectively. Both parasites are endemic in Israel and have been reported to infect wild and domestic animals. This study was conceived to evaluate the serologic exposure of donkeys to these parasites. Serum samples were collected from 98 donkeys. Half of them $(n=49)$ were from animal shelters in Israel, and the rest $(n=49)$ were working donkeys from the Palestinian Authority. The donkeys were screened for the presence of anti-Toxoplasma and anti-Neospora antibodies by immunofluorescence antibody tests (IFATs). The seroprevalence of T. gondii and Neospora spp. was $94 \%$ and $70 \%$, respectively, and $69 \%$ of the donkeys were exposed to both parasites. In addition, N. caninum tissue cysts were documented in two donkeys during post-mortem examination. This is the first report of the exposure of donkeys to T. gondii and Neospora spp. in the area. The high prevalence found in this study suggests that donkeys may have a role in the maintenance of these parasites in the area, thus serving as a source of infection for the definitive hosts. 
Keywords: Toxoplasma gondii; Neospora; donkey; IFAT; serology

\section{Introduction}

Cyst-forming coccidian parasites, mainly Toxoplasma gondii and Neospora spp., are major pathogens of animals with worldwide distribution. These closely related apicomplexan intracellular parasites have heteroxenous life cycles, with felids being the definitive hosts of T. gondii and canids of N. caninum. Both parasites infect various mammalian species as intermediate hosts in which they form tissue cysts [1].

Toxoplasmosis may cause abortions, fetal damage or neurologic disease in a wide range of animals and humans. It is a prominent cause of abortion in sheep and a common zoonosis [1-4]. The clinical significance of $T$. gondii infection in horses is unclear. Nevertheless, horses may be exposed to or infected by the $T$. gondii parasite with no apparent clinical signs, and may pose a zoonotic risk through the consumption of infective horse or donkey meat [5-7]. In Israel, the seroprevalence of T. gondii was evaluated as $20-60 \%$ in humans [ 8$], 25 \%$ in sheep [9], 36\% in dogs [10], $17 \%$ in cats [11], $43 \%$ in crows, $40 \%$ in Griffon vultures [12] and $2.5 \%$ in horses [13].

Neosporosis causes abortion and neurologic disease in various animals. Neospora caninum is a major cause of abortion and economic loss in the cattle industry, and has been reported in horses $[1,14]$. Neospora hughesi is known to affect only equids and was isolated from cases of neurological disease in horses [14,15]. These two species are indistinguishable when using standard serological methods [16]. Horses may be infected with both parasites, and since most surveys were based on serology, the reported prevalence in horses and donkeys was of Neospora spp. In Israel, the seroprevalence of Neospora spp. was evaluated as $51 \%$ in cattle [17], $1.3-67 \%$ in wild animals [18] and $12 \%$ in horses [19]. The seroprevalence in aborting mares and cows was significantly higher than in the general population $[17,19]$.

Domestic donkeys (Equus africanus acinus) in Israel are used as draught animals, riding animals, as pets and in petting zoos, and therefore are in close contact with humans. In other countries, donkeys are also used for their meat as food, and certain donkey-derived items are also important for traditional Chinese medicinal purposes [20]. Since donkeys are closely related to horses, they may be affected by similar pathogens. Exposure to both parasites has been reported in donkeys worldwide [5,6,21-27]. However, little is known about the role of donkeys in the epidemiology of these parasites. In Israel, data concerning the exposure of donkeys to infectious diseases are scarce. The aim of this study was to assess whether donkeys in Israel are exposed to T. gondii and Neospora spp. protozoan parasites, and to report two neosporosis cases of affected donkeys.

\section{Materials and Methods}

\subsection{Sample Collection for Serological Survey}

The sample size was calculated according to the prevalence of Neospora spp. in horses in Israel $(12 \%)$ [19] using WinPepi $11.43^{\circledR}$. A sample size of 77 donkeys met the criteria for an expected prevalence under $30 \%$, with a relative error of $\leq 20 \%$ and $95 \%$ confidence level.

Since no data are available for estimating the distribution of donkeys in Israel, it was unfeasible to design a sample that would reliably represent the donkey population in the area. Therefore, donkeys were sampled at two donkey shelters in Israel that receive donkeys from different locations (49 donkeys), and at three locations in the Palestinian Authority (PA) to which working animals were brought to receive veterinary care given through a humanitarian association ( 49 donkeys).

Blood collections were performed with owners' consent, and the study was approved by the Internal Research Review Committee of the Koret School of Veterinary Medicine-Veterinary Teaching Hospital (KSVM-VTH/23_2014). Blood was collected from the jugular vein of each animal into a sterile vacuum tube without anticoagulant. Sera were obtained from the clotted blood samples 
by centrifugation $\left(4000 \times g\right.$ for $10 \mathrm{~min}$ ) and stored at $-20^{\circ} \mathrm{C}$ until processing. During sample collection, data for each donkey were recorded including the farm's location, sex, age, and origin of the donkey, when available. At the time of sampling, all donkeys were apparently healthy according to both the owners and the veterinarians who collected the samples.

\subsection{Serological Screening Using Immunofluorescence Antibody Test (IFAT)}

Serological screening for the presence of anti-T. gondii antibodies was conducted on 1:2 serial dilutions of the sera, starting at 1:64 as a cut-off value for screening [28,29], up to a final dilution of $1: 16,384$.

Serological screening for the presence of anti-Neospora spp. antibodies was conducted on 1:2 serial dilutions of the sera, starting at 1:50 as a cut-off value for screening $[19,25,29]$, up to a final dilution of 1:3200.

In-house antigens were prepared as previously described [30]. Briefly, free tachyzoites were obtained from an infected Vero cell culture, separated by centrifugation, diluted in phosphate buffered saline (PBS), dropped onto slides and stored at $-80^{\circ} \mathrm{C}$ until use. The slides were thawed at $37^{\circ} \mathrm{C}$ for $30 \mathrm{~min}$ and air dried. The sera were diluted in PBS with $1 \%$ bovine serum albumin (BSA). A volume of $35 \mu \mathrm{L}$ of serum was added to each antigen drop well and incubated in a humid chamber at $37^{\circ} \mathrm{C}$ for $30 \mathrm{~min}$. The slides were washed for $10 \mathrm{~min}$ in carbonate buffer ( $\mathrm{pH}$ 9, diluted 1:4 in distilled water) before the application of $35 \mu \mathrm{L}$ of anti-horse fluorescein isothiocyanate (FITC) secondary antibody (Sigma-Aldrich, St. Louis, MO, USA) diluted 1:80 with PBS-BSA, and incubation at $37^{\circ} \mathrm{C}$ for $30 \mathrm{~min}$ in a humid chamber. The slides were later washed for $10 \mathrm{~min}$ in carbonate buffer, dried, mounted with glycerol/carbonate buffer $(50 \%)$ and examined under a fluorescence microscope. Positive and negative control serum samples from positive horses were added to each run.

\subsection{Statistical Analysis of Serology Results}

Risk factors associated with exposure to either parasite or both parasites were assessed separately and included the farm, the geographical area (Israel versus the Palestinian Authority), the donkey's sex and age. Association with nominal independent variables was assessed by using the $\chi^{2}$ test or Fisher's exact test, as appropriate, and odds ratios were calculated. Association with quantitative parameters was assessed using $t$-tests. Association between potential risk factors and antibody titer was assessed using ANOVA. Statistical significance was set at $p<0.05$. The analysis was performed using the SPSS $22.0^{\circledR}$ and Win Pepi $11.43^{\circledR}$ statistical software.

\subsection{Sample Collection, Histopathology and Polymerase Chain Reaction (PCR) of Clinical Samples}

Skeletal muscle tissue from the triceps brachi muscle was collected from two donkeys (Donkeys 1 and 2) and was sent to the Kimron Veterinary Institute pathology department for post-mortem examination. Brain tissue was collected from one of these donkeys (Donkey 1), which was reported to have neurological signs prior to euthanasia, and stored at $-20{ }^{\circ} \mathrm{C}$ until processing. Muscle tissue samples were transferred into $4 \%$ formaldehyde solution before the preparation of histological slides with hematoxylin and eosin (H\&E) staining.

DNA was extracted from the paraffin-embedded muscle tissue dissolved in xylene and washed with PBS, using the DNeasy blood and tissue kit (QIAGEN, Hilden, Germany) according to the manufacturer's instructions. The presence of coccidian parasites was confirmed using PCR targeting the small-subunit rRNA (COC1 F: AAGTATAAGCTTTTATACGGCT, COC2 R: CACTGCCACGGTAGTCCAATAC), and the classification of the species was achieved by sequenceand species-specific PCRs targeting Besnoitia besnoiti, Hammonidia, N. caninum, Sarcocystis spp., T. gondii and Trypanosoma spp. (the primers and targets are specified in Table 1).

RNA was extracted from brain tissue, and the presence of West Nile virus (WNV) RNA was tested for and confirmed by real-time reverse transcription PCR (qRT-PCR) and further amplified and sequenced, as previously described [31]. 
Table 1. The PCR primers used to identify the coccidian species of the tissue cysts found in donkeys' muscle tissue.

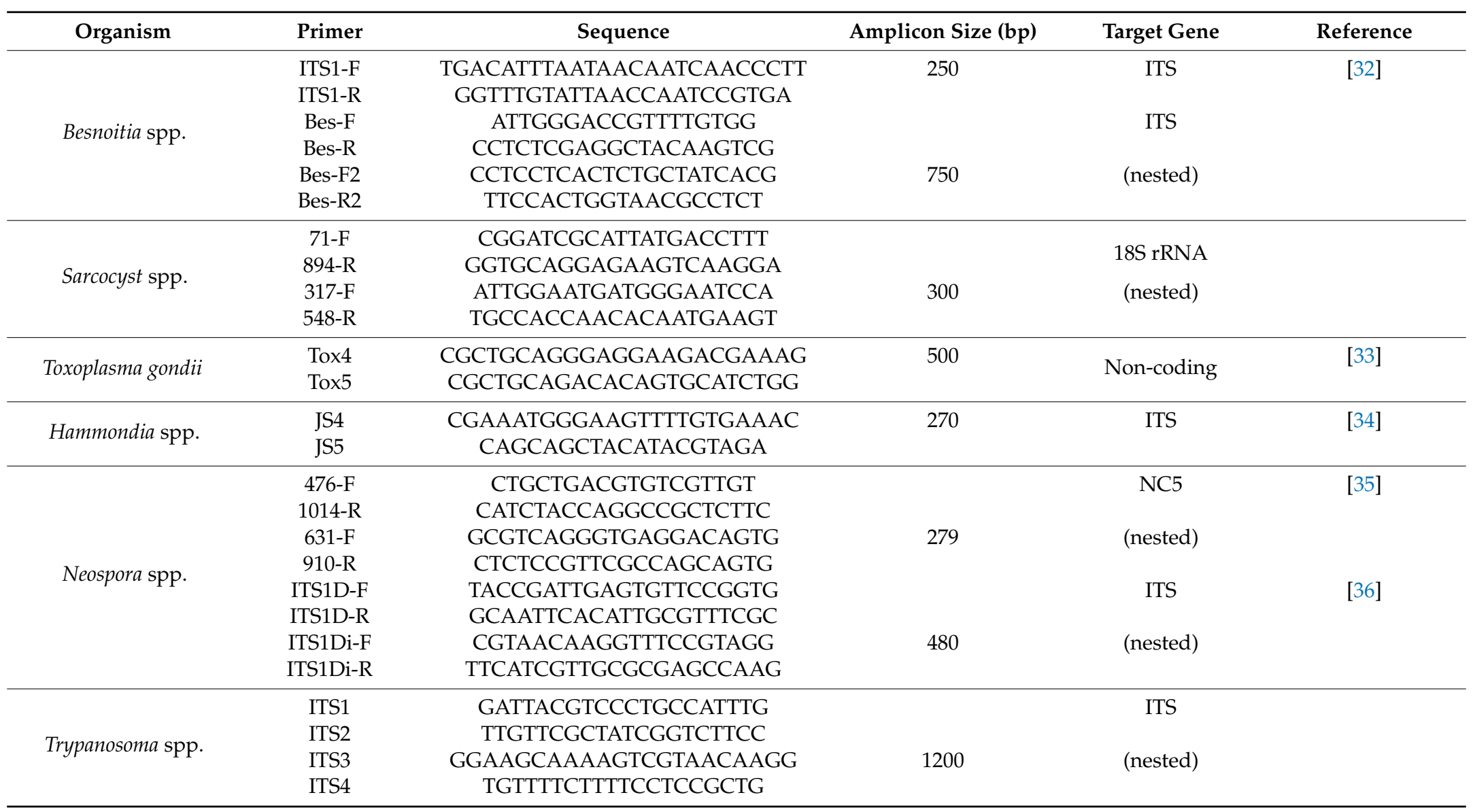


All positive PCR products were sent for sequencing by HyLabs (Rehovot, Israel). Sequences were evaluated using the Chromas software (Technelysium Pty Ltd., Tewantin, QLD, Australia, version 2.6) and assembled using the MEGA7 software (http://www.megasoftware.net, version 7.0.18). Consensus sequences were created for each gene from both donkeys and were submitted to GenBank.

\section{Results}

\subsection{Serologic Exposure to T. gondii and Neospora Spp. in Donkeys}

The study population comprised donkeys from Israel $(n=49)$ and the Palestinian Authority $(n=49)$. Sixty of the donkeys were males $(61 \%)$, and 38 were females $(39 \%)$. Age was available for 70 of the donkeys and ranged between four months and 25 years (mean $=7.6$ years, median $=7.0$ years, standard deviation $=5.1$ years). All donkeys were apparently healthy during blood collection.

Anti-T. gondii antibodies were detected in 92 of 98 donkeys (94\%). The antibody titers ranged between 1:64 and 1:16,384 (Figure 1a), while high titers $(\geq 1: 256)$ were found in $66 \%$ of the animals. No significant risk factors for exposure were identified.

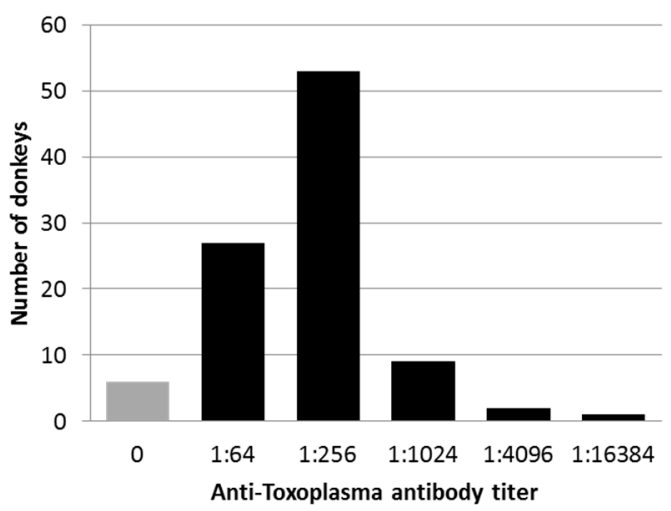

(a)

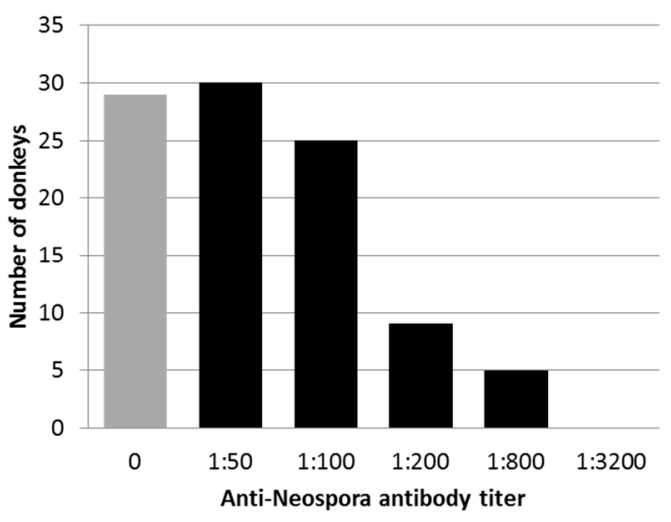

(b)

Figure 1. The distribution of anti-T. gondii (a) and anti-Neospora spp. (b) antibody titers in 98 donkeys, as detected by immunofluorescence antibody tests (IFATs).

Anti-Neospora spp. antibodies were detected in 69 of 98 donkeys (70\%). The antibody titers ranged between 1:50 and 1:800 (Figure $1 \mathrm{~b}$ ), while high titers $(\geq 1: 200)$ were found in $14 \%$ of the animals. No significant risk factors for exposure were identified. High antibody titers $(\geq 1: 200)$ were associated with one farm in Israel. In this farm, 10 out of 25 donkeys had high antibody titers, representing $71.4 \%$ (10 of 14) of the donkeys with high antibody titers $(p>0.001$, odds ratio $(\mathrm{OR})=11.5,95 \%$ confidence interval $(\mathrm{CI})=2.76-55.29)$.

The majority of donkeys $(68 / 98,69.4 \%)$ were exposed to both parasites. An additional 24 donkeys (24.5\%) were exposed only to Toxoplasma gondii, one donkey (1\%) was exposed only to Neospora spp., and five donkeys (5.1\%) were not exposed to any of these parasites. No significant risk factors for co-exposure were identified.

\subsection{Clinical Cases of Neosporosis in Donkeys}

Parasitic tissue cysts were identified in the skeletal muscles of two donkeys sent for post-mortem examination (Figure 2). Both donkeys were sent from the same animal shelter. The first donkey (Donkey 1) was over 30 years old and presented with neurological signs and severe weakness before euthanasia. The second donkey (Donkey 2) was over 20 years old, and his left thoracic limb had been amputated several years prior to his death from unrelated causes. After his demise, the right thoracic limb was sent for evaluation for any potential effect of the amputation on the contralateral limb. The donkey that had presented with neurological signs (Donkey 1) was diagnosed as being infected 
with WNV after viral RNA was isolated and sequenced from its brain tissue (MT828577). In both donkeys, multifocal tissue cysts containing parasites were observed (Figure 2). Neospora caninum DNA was identified in the skeletal muscle tissue of both donkeys and was confirmed by the sequencing of two different species-specific target genes (NC5 (MT831977) and ITS1 (MT826198), over 97\% homology with species-specific sequences in GenBank). Specific PCRs targeting Besnoitia spp., Hammonidia, T. gondii, Neospora spp., Sarcocystis spp., T. gondii and Trypanosoma spp. were negative, and the presence of these related cyst-forming parasites was ruled out.

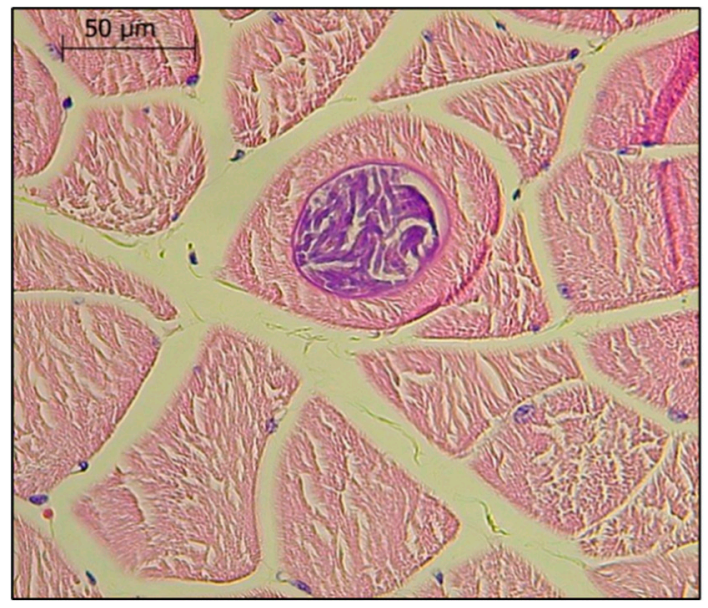

(a)

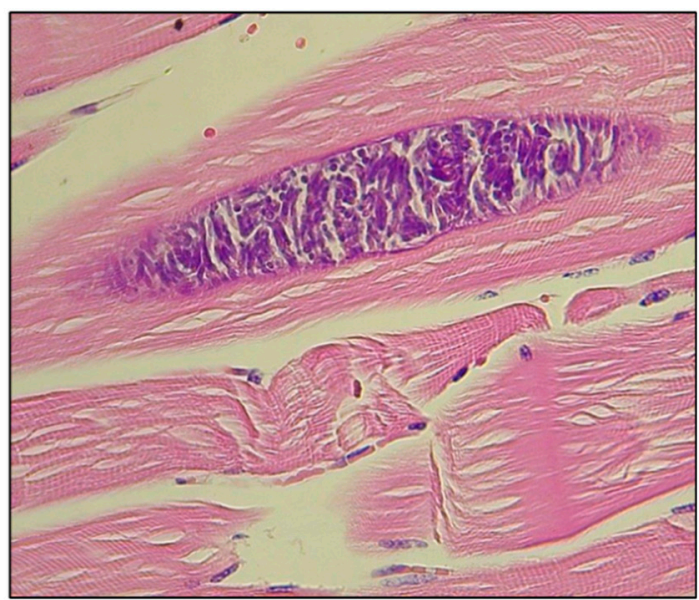

(b)

Figure 2. Neospora caninum tissue cysts in the skeletal muscles of the front limb of Donkey 1: (a) transverse section; (b) longitudinal section. Giemsa, $\times 1000$.

\section{Discussion}

The seroprevalence of both T. gondii and N. caninum in donkeys in Israel is high, and higher than the recorded prevalence in any other mammalian species in the area, including horses $[13,18]$. Donkeys in Israel are sometimes kept as burden animals, being more prevalent in Arab and Bedouin villages and often receiving little veterinary care, in comparison to horses. Half of the donkeys in this survey were sampled in animal shelters that receive neglected donkeys from various locations, while the other half were sampled in Arab villages in the Palestinian authority, by a veterinarian giving free veterinary care through a humanitarian organization. The high exposure to both parasites may be the result of the poor sanitation associated with low-income populations, which may increase the chance of exposure to oocysts in water sources or the environment. The association between low income and higher exposure to $T$. gondii has been previously described in humans and in horses $[7,37,38]$. In addition, in poor sanitary conditions, stray dogs and cats may have access to and feed on donkey carcasses, thus enhancing the maintenance and transmission of Neosporosis and Toxoplasmosis in these areas.

The seroprevalence of $T$. gondii in horses varies between countries and ranges between $1.2 \%$ in Sweden [39] and 71.2\% in Iran [40]. The differences in prevalence may be associated with housing, stable hygiene and feeding practices $[7,41]$. The prevalence of $T$. gondii was higher in donkeys $(72.7 \%)$ than in horses (27.7\%) in a recent study from Brazil [42], as well as in other studies from Spain [23] and Pakistan [43]. However, since there are fewer studies evaluating both horses and donkeys in similar cohorts, it is difficult to determine whether these differences reflect a higher susceptibility of donkeys, or merely reflect differences in sanitation or management practices between these species. Since horses are considered to be naturally resistant to $T$. gondii infection [42], it is possible that they develop lower antibody titers that are not detected by serological tests.

In Israel, T. gondii seroprevalence was significantly higher in the Arab population (60.4\%) than in Bedouins (27.5\%) or Jews (19.9\%) [8], and similar to the reported prevalence in Lebanon $(62.2 \%)$ [44]. The seroprevalence was age-dependent and reached $96 \%$ in Arabs over 60 years of age [8]. 
The differences within ethnic groups in Israel may be attributable to a combination of economic status, exposure to animals and climate [8]. Since donkeys in Israel are more abundant in Arab settlements, the high seroprevalence may reflect similar conditions for exposure.

Although the consumption of donkey or horse meat is not common in this area, infection from contaminated meat is still a potential source for zoonotic transmission. Viable T. gondii parasites have been isolated from horse and donkey meat intended for human consumption worldwide [5,6,45-47], with a possible link to human disease [46].

In a recent study [48], an association between $T$. gondii seropositivity and the prevalence of impaired cognitive function was demonstrated in humans. Researchers theorize that behavior manipulation increases the parasite's likelihood of transmission by manipulating the host to engage in risky behaviors so that the host is likely to be preyed upon, particularly by a feline [48]. This was demonstrated in rats [49]. In this study, behavioral changes were not observed in any of the animals. To the best of our knowledge, behavioral changes have never been reported in equids in regard to T. gondii infection.

Neosporosis is not considered zoonotic, and its main impact is economic, mostly due to its effect on the reproduction of cattle and small ruminants, which are considered as the main intermediate hosts $[14,50]$. Therefore, fewer data are available regarding its prevalence in equines. In Israel, the prevalence in horses (12\%) [19] was considerably lower than our findings in donkeys (70\%). In neighboring Jordan, the reported seroprevalence in horses was 32\% [51], and that in small ruminants was 63\% [52]. Both dogs and donkeys often accompany small ruminant flocks in the Middle East, which may increase the chance of infection of both the primary and secondary hosts. In 1998, a new species of Neospora, N. hughesi, was identified in a horse from California [15]. Since then, N. hughesi has been reported only in horses and mostly from North America; however, since the two Neospora species are indistinguishable serologically, the global distribution of $N$. hughesi is unclear [14]. In the two cases of tissue cysts described here, parasites were classified as N. caninum based on two loci. In addition, $N$. caninum was identified in several cases of Neospora-induced abortion in mares in Israel (Mazuz et al., unpublished data), while N. hughesi has never been described in the area.

In horses, both toxoplasmosis and neosporosis had been associated with neurological disease, while neosporosis had also been described as a cause of abortions and neonatal disease [53,54]. However, reports of equine clinical cases are rare, and the majority of seropositive horses are asymptomatic. The clinical significance of high exposure to these parasites in donkeys is unclear. All donkeys in this study were apparently healthy, and to the best of our knowledge, clinical toxoplasmosis or neosporosis in donkeys has never been reported in Israel or elsewhere. Although one of the clinical cases in this report (Donkey 1) exhibited marked neurological signs, the cause of the neurological disease was determined as WNV, which is the most common cause of neurological disease in horses in the area [55]. Nevertheless, the identification of N. caninum tissue cysts in muscle specimens from two donkeys suggests that donkeys may be susceptible to clinical infection.

\section{Conclusions}

This is the first epidemiological survey investigating the exposure of donkeys to T. gondii and N. caninum in Israel. The high seroprevalence of both parasites in donkeys may reflect a high susceptibility of this species or high exposure due to poor husbandry conditions. The pathological findings of $N$. caninum tissue cysts in two donkeys suggest that donkeys may also be clinically infected and highlight the potential of donkeys to be a source of infection to other animal species. The higher exposure of donkeys in relation to other animal species in these areas suggests that donkeys could be used as sentinels to monitor exposure to these important, and potentially zoonotic, parasites.

Author Contributions: Conceptualization, A.S., M.L.M. and S.T.-L.; formal analysis, S.T.-L.; investigation, A.M., G.S., L.F., N.E. and I.S.; resources, S.T.-L., M.L.M., A.S. and O.A.; writing-original draft preparation, S.T.-L.; writing-review and editing, A.S. and M.L.M.; supervision, M.L.M. All authors have read and agreed to the published version of the manuscript.

Funding: This research received no external funding. 
Acknowledgments: The authors wish to thank the workers of the donkey shelters and the workers in the veterinary clinics in the Palestinian Authority for their assistance and collaboration.

Conflicts of Interest: The authors declare no conflict of interest.

\section{References}

1. Dubey, J.P.; Lindsay, D.S. Neosporosis, toxoplasmosis, and sarcocystosis in ruminants. Vet. Clin. North. Am. Food Anim. Pract. 2006, 22, 645-671. [CrossRef] [PubMed]

2. Benavides, J.; Fernandez, M.; Castano, P.; Ferreras, M.C.; Ortega-Mora, L.; Perez, V. Ovine toxoplasmosis: A new look at its pathogenesis. J. Comp. Pathol. 2017, 157, 34-38. [CrossRef] [PubMed]

3. Dubey, J.P. Toxoplasmosis in sheep-The last 20 years. Vet. Parasitol. 2009, 163, 1-14. [CrossRef]

4. Dubey, J.P. Toxoplasmosis of Animals and Humans; CRC Press: Boca Raton, FL, USA, 2016.

5. Alvarado-Esquivel, C.; Alvarado-Esquivel, D.; Dubey, J.P. Prevalence of Toxoplasma gondii antibodies in domestic donkeys (Equus asinus) in Durango, Mexico slaughtered for human consumption. BMC Vet. Res. 2015, 11, 6. [CrossRef]

6. Cong, W.; Chen, L.; Shan, X.F.; Qian, A.D.; Meng, Q.F. First genetic characterization of Toxoplasma gondii infection in donkey meat slaughtered for human consumption in Shandong province, eastern China. Infect. Genet. Evol. 2018, 61, 1-3. [CrossRef] [PubMed]

7. Li, X.; Ni, H.B.; Ren, W.X.; Jiang, J.; Gong, Q.L.; Zhang, X.X. Seroprevalence of Toxoplasma gondii in horses: A global systematic review and meta-analysis. Acta Trop. 2020, 201, 105222. [CrossRef] [PubMed]

8. Markovich, M.P.; Shohat, T.; Riklis, I.; Avni, R.; Yujelevski-Rozenblit, D.; Bassal, R.; Cohen, D.; Rorman, E. Seroepidemiology of Toxoplasma gondii infection in the Israeli population. Epidemiol. Infect. 2014, 142, $149-155$. [CrossRef] [PubMed]

9. Shkap, V.; Pipano, E.; Marcus, S.; Rapoport, E. The prevalence of Toxoplasma gondii antibodies in sheep and cattle in Israel. Isr. J. Vet. Med. 1992, 47, 100.

10. Baneth, G.; Shkap, V.; Savitsky, I.; Pipano, E. The prevalence of antibodies to Toxoplasma gondii in dogs in Israel. Isr. J. Vet. Med. 1996, 51, 31-34.

11. Salant, H.; Spira, D.T. A cross-sectional survey of anti-Toxoplasma gondii antibodies in Jerusalem cats. Vet. Parasitol. 2004, 124, 167-177. [CrossRef]

12. Salant, H.; Hamburger, J.; King, R.; Baneth, G. Toxoplasma gondii prevalence in Israeli crows and Griffon vultures. Vet. Parasitol. 2013, 191, 23-28. [CrossRef]

13. Aharonson-Raz, K.; Baneth, G.; Lopes, A.P.; Brancal, H.; Schallig, H.; Cardoso, L.; Steinman, A. Low Seroprevalence of Leishmania infantum and Toxoplasma gondii in the Horse Population in Israel. Vector Borne Zoonotic Dis. 2015, 15, 726-731. [CrossRef]

14. Dubey, J.; Hemphill, A.; Calero-Bernal, R.; Schares, G. Neosporosis in Animals; CRC Press: Boca Raton, FL, USA, 2017.

15. Marsh, A.E.; Barr, B.C.; Packham, A.E.; Conrad, P.A. Description of a new Neospora species (Protozoa: Apicomplexa: Sarcocystidae). J. Parasitol. 1998, 84, 983-991. [CrossRef] [PubMed]

16. Marsh, A.E.; Howe, D.K.; Wang, G.; Barr, B.C.; Cannon, N.; Conrad, P.A. Differentiation of Neospora hughesi from Neospora caninum based on their immunodominant surface antigen, SAG1 and SRS2. Int. J. Parasitol. 1999, 29, 1575-1582. [CrossRef]

17. Mazuz, L.M.; Fish, L.; Molad, T.; Savitsky, I.; Wolkomirsky, R.; Leibovitz, B.; Shkap, V. Neospora Caninum as Causative-Pathogen of Abortion in Cattle. Isr. J. Vet. Med. 2011, 66, 14-18.

18. Mazuz, M.L.; Alvarez-Garcia, G.; King, R.; Savisky, I.; Shkap, V.; Ortega-Mora, L.M.; Gutierrez-Exposito, D. Exposure to Neospora spp. and Besnoitia spp. in wildlife from Israel. Int. J. Parasitol. Parasites Wildl. 2018, 7, 317-321. [CrossRef] [PubMed]

19. Kligler, E.B.; Shkap, V.; Baneth, G.; Mildenberg, Z.; Steinman, A. Seroprevalence of Neospora spp. among asymptomatic horses, aborted mares and horses demonstrating neurological signs in Israel. Vet. Parasitol. 2007, 148, 109-113. [CrossRef] [PubMed]

20. Bennett, R.; Pfuderer, S. The Potential for New Donkey Farming Systems to Supply the Growing Demand for Hides. Animals 2020, 10, 718. [CrossRef]

21. Cong, W.; Nie, L.B.; Qin, S.Y.; Wang, W.L.; Qian, A.D.; Meng, Q.F. Prevalence of Neospora spp. in donkeys in China. Parasite 2018, 25. [CrossRef] 
22. Galvao, C.M.M.D.; Rezende-Gondim, M.M.; Chaves, A.C.R.; Schares, G.; Ribas, J.R.L.; Gondim, L.F.P. Brazilian donkeys (Equus asinus) have a low exposure to Neospora spp. Rev. Bras. Parasitol. 2015, 24, 340-344. [CrossRef] [PubMed]

23. Garcia-Bocanegra, I.; Cabezon, O.; Arenas-Montes, A.; Carbonero, A.; Dubey, J.P.; Perea, A.; Almeria, S. Seroprevalence of Toxoplasma gondii in equids from Southern Spain. Parasitol. Int. 2012, 61, 421-424. [CrossRef]

24. Gennari, S.M.; Esmerini, P.D.; Lopes, M.G.; Soares, H.S.; Vitaliano, S.N.; Cabral, A.D.; Pena, H.F.J.; Horta, M.C.; Cavalcante, P.H.; Fortes, K.P.; et al. Occurrence of antibodies against Toxoplasma gondii and its isolation and genotyping in donkeys, mules, and horses in Brazil. Vet. Parasitol. 2015, 209, 129-132. [CrossRef] [PubMed]

25. Gennari, S.M.; Pena, H.F.D.; Lindsay, D.S.; Lopes, M.G.; Soares, H.S.; Cabral, A.D.; Vitaliano, S.N.; Amaku, M. Prevalence of antibodies against Neospora spp. and Sarcocystis neurona in donkeys from northeastern Brazil. Rev. Bras. Parasitol. 2016, 25, 109-111. [CrossRef] [PubMed]

26. Machacova, T.; Bartova, E.; Di Loria, A.; Sedlak, K.; Guccione, J.; Fulgione, D.; Veneziano, V. Seroprevalence and risk factors of Neospora spp. in donkeys from Southern Italy. Vet. Parasitol. 2013, 198, 201-204. [CrossRef] [PubMed]

27. Nazir, M.M.; Ayaz, M.M.; Ahmed, A.N.; Rasheed, I.; Faraz, A.; Akram, Q.; Althtar, S.; Maqbool, A.; Tabassum, S.; Zheng, Y.D.; et al. Prevalence and risk factors for IgG antibodies to Neospora spp. in three types of equids from Southern Punjab, Pakistan. Acta Trop. 2018, 188, 240-243. [CrossRef] [PubMed]

28. Dubey, J.P.; Murata, F.H.A.; Cerqueira-Cezar, C.K.; Kwok, O.C.H. Toxoplasma gondii infections in horses, donkeys, and other equids: The last decade. Res. Vet. Sci. 2020, 132, 492-499. [CrossRef]

29. Moreira, T.R.; Sarturi, C.; Stelmachtchuk, F.N.; Andersson, E.; Norlander, E.; de Oliveira, F.L.C.; Machado Portela, J.; Marcili, A.; Emanuelson, U.; Gennari, S.M.; et al. Prevalence of antibodies against Toxoplasma gondii and Neospora spp. in equids of Western Para, Brazil. Acta Trop. 2019, 189, 39-45. [CrossRef]

30. Shkap, V.; Reske, A.; Pipano, E.; Fish, L.; Baszler, T. Immunological relationship between Neospora caninum and Besnoitia besnoiti. Vet. Parasitol. 2002, 106, 35-43. [CrossRef]

31. Schvartz, G.; Farnoushi, Y.; Berkowitz, A.; Edery, N.; Hann, S.; Steinman, A.; Lublin, A.; Erster, O. Molecular characterization of the re-emerging West Nile Virus in avian species and equids in Israel, and pathological description of the disease. Parasit. Vectors 2018, in press.

32. Cortes, H.C.; Reis, Y.; Gottstein, B.; Hemphill, A.; Leitao, A.; Muller, N. Application of conventional and real-time fluorescent ITS1 rDNA PCR for detection of Besnoitia besnoiti infections in bovine skin biopsies. Vet. Parasitol. 2007, 146, 352-356. [CrossRef]

33. Homan, W.L.; Vercammen, M.; De Braekeleer, J.; Verschueren, H. Identification of a 200- to 300-fold repetitive 529 bp DNA fragment in Toxoplasma gondii, and its use for diagnostic and quantitative PCR. Int. J. Parasitol. 2000, 30, 69-75. [CrossRef]

34. Slapeta, J.R.; Koudela, B.; Votypka, J.; Modry, D.; Horejs, R.; Lukes, J. Coprodiagnosis of Hammondia heydorni in dogs by PCR based amplification of ITS 1 rRNA: Differentiation from morphologically indistinguishable oocysts of Neospora caninum. Vet. J. 2002, 163, 147-154. [CrossRef] [PubMed]

35. Fish, L.; Mazuz, M.; Molad, T.; Savitsky, I.; Shkap, V. Isolation of Neospora caninum from dairy zero grazing cattle in Israel. Vet. Parasitol. 2007, 149, 167-171. [CrossRef] [PubMed]

36. Wobeser, B.K.; Godson, D.L.; Rejmanek, D.; Dowling, P. Equine protozoal myeloencephalitis caused by Neospora hughesi in an adult horse in Saskatchewan. Can. Vet. J. 2009, 50, 851-853. [PubMed]

37. Rostami, A.; Riahi, S.M.; Contopoulos-Ioannidis, D.G.; Gamble, H.R.; Fakhri, Y.; Shiadeh, M.N.; Foroutan, M.; Behniafar, H.; Taghipour, A.; Maldonado, Y.A.; et al. Acute Toxoplasma infection in pregnant women worldwide: A systematic review and meta-analysis. PLoS Negl. Trop. Dis. 2019, 13, e0007807. [CrossRef] [PubMed]

38. Rostami, A.; Riahi, S.M.; Gamble, H.R.; Fakhri, Y.; Nourollahpour Shiadeh, M.; Danesh, M.; Behniafar, H.; Paktinat, S.; Foroutan, M.; Mokdad, A.H.; et al. Global prevalence of latent toxoplasmosis in pregnant women: A systematic review and meta-analysis. Clin. Microbiol. Infect. 2020, 26, 673-683. [CrossRef] [PubMed]

39. Jakubek, E.B.; Lunden, A.; Uggla, A. Seroprevalences of Toxoplasma gondii and Neospora sp. infections in Swedish horses. Vet. Parasitol. 2006, 138, 194-199. [CrossRef] [PubMed]

40. Hajialilo, E.; Ziaali, N.; Harandi, M.F.; Saraei, M.; Hajialilo, M. Prevalence of anti-Toxoplasma gondii antibodies in sport horses from Qazvin, Iran. Trop. Anim. Health Prod. 2010, 42, 1321-1322. [CrossRef] 
41. Tenter, A.M.; Heckeroth, A.R.; Weiss, L.M. Toxoplasma gondii: From animals to humans. Int. J. Parasitol. 2000, 30, 1217-1258. [CrossRef]

42. Munhoz, A.D.; Souza, M.A.; Costa, S.C.L.; Freitas, J.S.; Silva, A.N.D.; Lacerda, L.C.; Cruz, R.D.S.; Albuquerque, G.R.; Pereira, M.J.S. Factors associated with the distribution of natural Toxoplasma gondii infection among equids in Northeastern Brazil. Rev. Bras. Parasitol. Vet. 2019, 28, 283-290. [CrossRef]

43. Saqib, M.; Hussain, M.H.; Sajid, M.S.; Mansoor, M.K.; Asi, M.N.; Fadya, A.A.; Zohaib, A.; Sial, A.U.; Muhammad, G.; Ullah, I. Sero-epidemiology of equine toxoplasmosis using a latex agglutination test in the three metropolises of Punjab, Pakistan. Trop. Biomed. 2015, 32, 276-285. [PubMed]

44. Bouhamdan, S.F.; Bitar, L.K.; Saghir, H.J.; Bayan, A.; Araj, G.F. Seroprevalence of Toxoplasma antibodies among individuals tested at hospitals and private laboratories in Beirut. J. Med. Liban 2010, 58, 8-11.

45. Shaapan, R.M.; Ghazy, A.A. Isolation of Toxoplasma gondii from horse meat in Egypt. Pak. J. Biol. Sci. 2007, 10, 174-177. [CrossRef]

46. Pomares, C.; Ajzenberg, D.; Bornard, L.; Bernardin, G.; Hasseine, L.; Darde, M.L.; Marty, P. Toxoplasmosis and horse meat, France. Emerg. Infect. Dis. 2011, 17, 1327-1328. [CrossRef] [PubMed]

47. Pastiu, A.I.; Gyorke, A.; Kalmar, Z.; Bolfa, P.; Rosenthal, B.M.; Oltean, M.; Villena, I.; Spinu, M.; Cozma, V. Toxoplasma gondii in horse meat intended for human consumption in Romania. Vet. Parasitol. 2015, 212, 393-395. [CrossRef]

48. Wiener, R.C.; Waters, C.; Bhandari, R. The association of Toxoplasma gondii IgG and cognitive function scores: NHANES 2013-2014. Parasitol. Int. 2020, 78, 102123. [CrossRef] [PubMed]

49. da Silva, R.C.; Langoni, H. Toxoplasma gondii: Host-parasite interaction and behavior manipulation. Parasitol. Res. 2009, 105, 893-898. [CrossRef]

50. Reichel, M.P.; Ayanegui-Alcérreca, M.A.; Gondim, L.F.; Ellis, J.T. What is the global economic impact of Neospora caninum in cattle-the billion dollar question. Int. J. Parasitol. 2013, 43, 133-142. [CrossRef] [PubMed]

51. Talafha, A.Q.; Abutarbush, S.M.; Rutley, D.L. Seroprevalence and Potential Risk Factors Associated with Neospora spp. Infection among Asymptomatic Horses in Jordan. Korean J. Parasitol. 2015, 53, 163-167. [CrossRef]

52. Abo-Shehada, M.N.; Abu-Halaweh, M.M. Flock-level seroprevalence of, and risk factors for, Neospora caninum among sheep and goats in northern Jordan. Prev. Vet. Med. 2010, 93, 25-32. [CrossRef]

53. James, K.E.; Smith, W.A.; Packham, A.E.; Conrad, P.A.; Pusterla, N. Toxoplasma gondii seroprevalence and association with equine protozoal myeloencephalitis: A case-control study of Californian horses. Vet. J. 2017, 224, 38-43. [CrossRef] [PubMed]

54. Lindsay, D.S. Neosporosis: An emerging protozoal disease of horses. Equine Vet. J. 2001, 33, 116-118. [CrossRef] [PubMed]

55. Aharonson-Raz, K.; Lichter-Peled, A.; Tal, S.; Gelman, B.; Cohen, D.; Klement, E.; Steinman, A. Spatial and temporal distribution of West Nile virus in horses in Israel (1997-2013)—from endemic to epidemics. PLoS ONE 2014, 9, e113149. [CrossRef] [PubMed]

Publisher's Note: MDPI stays neutral with regard to jurisdictional claims in published maps and institutional affiliations.

(C) 2020 by the authors. Licensee MDPI, Basel, Switzerland. This article is an open access article distributed under the terms and conditions of the Creative Commons Attribution (CC BY) license (http://creativecommons.org/licenses/by/4.0/). 